\title{
East Asia and the European Union: Partners in Global Economic Governance
}

\section{Guest-Editors' Introduction}

\author{
Sebastian Bersick ${ }^{1}$ (D) Werner Pascha ${ }^{2}$
}

Received: 3 July 2019 / Revised: 3 July 2019 / Accepted: 16 July 2019 / Published online: 29 July 2019 (c) Asiatic Research Institute 2019

In times of profound political and societal changes, economic globalization takes on a new meaning. New actors and alliances are gaining importance relative to old ones. This special issue on "East Asia and the European Union: Partners in Global Economic Governance" focuses on the topic of global governance and the role that European and East Asian actors and institutions play within it. All contributions explore how and why actors and institutions in Europe and East Asia are engaging in multilateral cooperation and the role of the domestic, regional and global levels in shaping their respective policies, behaviour and relations among both regions and on the global stage.

The special issue falls into two volumes and consists of papers that were firstly presented during a workshop at Ruhr University Bochum (RUB), Germany, on the eve of the Hamburg G20 summit in 2017. The aim of the workshop that brought together scholars and think-tankers from Europe and Asia was to identify actors, issues, institutions and venues in global governance, where East Asia and the European Union (could) act as partners. By identifying East Asian state and non-state actors as partners in global governance, the workshop also addressed theoretical and policy implications of the changing US foreign policy and the latter's impact on problem solving capacities in different areas of global governance, particularly in the economic, financial and environmental realm. The workshop was supported by the European Union's Jean Monnet programme and by its Jean Monnet Chair on "The International Political Economy of EU-Asia Relations", located at the Faculty of East Asian Studies, Department of International Political Economy of East Asia, RUB. It was organized in cooperation with the School of International Relations and Public Affairs (SIRPA), Fudan University in Shanghai, and forms part of

Sebastian Bersick

sebastian.bersick@rub.de

Werner Pascha

werner.pascha@uni-due.de

1 Faculty of East Asian Studies, Ruhr University Bochum, 44801 Bochum, Germany

2 Institute of East Asian Studies and Mercator School of Management, University of Duisburg-Essen, 47048 Duisburg, Germany 
the collaboration between the University Duisburg-Essen (UDE) and RUB in the framework of the Alliance for Research on East Asia Ruhr (AREA Ruhr).

This first volume encompasses a group of four papers. Questioning the efficiency of intensive globalization, Werner Pascha introduces the idea of a "regional policy space". In his conceptual paper "The Globalization Trilemma and Regional Policy Space: Opportunities and Challenges for the EU and East Asia", he discusses the challenge that economies in Asia, Europe and elsewhere are experiencing, namely that national sovereignty, globalization and democracy cannot be had at the same time. As he argues, a region-based approach to the challenge of the globalization trilemma could provide multilateral public goods and multilateral solutions with greater depth and width than national schemes. Based on his framework of analysis, he is somewhat sceptical about transnational schemes.

In her contribution, Bernadette Andreosso O'Callaghan deals with “The G20 Growth Challenge in the Framework of EU East-Asia Economic Relations". She approaches the topic from a macroeconomic level of analysis, discusses the G20's progress in terms of achieving a number of economic objectives centred on the economic challenge of growth revitalization and assesses longer-term factors such as a weakening European Union, the People's Republic of China (China) increasingly assertive behaviour in world economic affairs and Japan's evolving regional and global aspirations.

Global financial governance and the changing relationship between the EU and China are in the focus of Nele Noesselt's article on "Sino-EU Cooperation 2.0: Toward a Global "Green Strategy?". Using a role theoretical approach and addressing changes in China's foreign strategy, like the Belt and Road Initiative (BRI), she discusses China's strategy vis-à-vis Europe as well as the recent changes in the EU's China policy. She argues that China's new interest in transregional and global regulatory frameworks of green finance results from the need of the domestic re-steering of the Chinese economy towards sustainable development and from the need to create a positive image of China's BRI-related investment activities. In addition to these factors, the changing global stance of the USA facilitates Sino-EU policy coordination in the new and innovative field of green financial governance.

Wang Xiaorui's article “China's Approach to Environmental Governance and the Role of the EU in Market-Induced Reforms" discusses how China's domestic environmental governance policies and mechanisms are co-shaped by market-induced forces that result from international trade. By analysing the discursive construction of China's National Ecological Accounting and Auditing Scheme (NEAS) and comparing it to sustainability-related trade imperatives, she discusses the institutional perception of these two approaches to ecological governance in China and the role of ecological standards for sustainability and fairness through global supply chains. Her research interest is twofold, as she also analyses the specific role of regulations from the EU and of the EU-China strategic partnership. Taking the Chinese agricultural sector and its exports as a case study, she arrives at the conclusion that China and the EU are very likely to engage in collaborating on environmental issues because of their economic and political interests.

All papers in this special issue ultimately aim at contributing to the literature and policy discourse on the role of East Asia and the EU with regard to the future of politics and global governance, the reform of global economic governance and regional contributions in defence of multilateralism. 